\title{
Characterization and partial purification of L-asparaginase from Corynebacterium glutamicum
}

\author{
Juan M. Mesas, José A. Gil and JuAn F. Martín* \\ Area de Microbiología, Facultad de Biologia, Universidad de León, 24071 León, Spain
}

(Received 7 November 1989; accepted 22 November 1989)

\begin{abstract}
A high L-asparaginase (L-asparagine amidohydrolase; EC 3.5.1.1) activity was found under conditions of lysine overproduction in cultures of Corynebacterium glutamicum. L-Asparaginase was purified 98-fold by protamine sulphate precipitation, DEAE-Sephacel anion exchange, ammonium sulphate precipitation and Sephacryl S-200 gel filtration. The asparaginase protein was subjected to PAGE under non-denaturing conditions, identified by an in situ reaction and eluted from the gel in an active form. The estimated $M_{\mathrm{r}}$ from gel filtration and SDS-PAGE was 80000. The L-asparaginase activity was inhibited by the L-asparagine analogue 5-diazo-4-oxo-L-norvaline. Neither D-asparagine nor L-glutamine was a substrate for the enzyme. L-Asparaginase was produced constitutively; its role may be that of an overflow enzyme, converting excess asparagine into aspartic acid, the direct precursor of lysine and threonine.
\end{abstract}

\section{Introduction}

L-Asparaginase (L-asparagine amidohydrolase; EC 3.5.1.1) catalyses the hydrolysis of $L$-asparagine to $\mathrm{L}$-aspartic acid and ammonia. In the presence of hydroxylamine this enzyme converts the activated Lasparagine into aspartyl $\beta$-hydroxamate (Wriston, 1970). This activity of the asparaginase is routinely used for the determination of enzyme activity.

Asparaginase has been studied in Escherichia coli and other Gram-negative bacteria such as the Achromobacteriaceae (Roberts et al., 1972) and Vibrio succinogenes (Kafkewitz \& Goodman, 1974).

Amino-acid-producing corynebacteria are of great industrial interest because they excrete large amounts of various amino acids (Martín et al., 1987; Martín, 1989). Lysine, threonine and methionine, three of the commercially important amino acids produced by Corynebacterium glutamicum, are derived from aspartic acid, which, under normal physiological conditions, might be limiting for lysine and/or threonine biosynthesis. Aspartic acid is formed from either Krebs' cycle intermediates using glutamic acid as the amino donor or from asparagine by the action of asparaginase. A very active L-asparaginase was found in C. glutamicum (in preliminary experiments) under lysine-producing fermentation conditions. In addition to their role in amino acid metabolism, several

Abbreviations: DONV, 5-diazo-4-oxo-L-norvaline; OPA, ophthaldialdehyde. asparaginases are of interest because of their antitumour properties (Handschumacher et al., 1968; Kafkewitz \& Goodman, 1974; Roberts et al., 1972; Willis \& Woolfolk, 1974). The asparaginases of Gram-positive bacteria have received little attention. Therefore, it was of interest to purify the L-asparaginase of $C$. glutamicum and to study its kinetics as a first step towards understanding its role in the biosynthesis of the aspartic acid family of amino acids.

\section{Methods}

Micro-organisms and growth conditions. Corynebacterium glutamicum ATCC 13032 (Abe et al., 1967), initially named Micrococcus glutamicus (Kinoshita et al., 1958), was used in this study. Cultures were grown aerobically in tryptone-soya broth (TSB) medium containing $\left(\mathrm{g}^{-1}\right)$ : casein peptone, 17; soya peptone, 3 ; glucose, $2.5 ; \mathrm{NaCl}, 5 ; \mathrm{K}_{2} \mathrm{HPO}_{4}$, $2 \cdot 5$; yeast extract, $1, \mathrm{pH} 7 \cdot 3$. Cultures were incubated at $30^{\circ} \mathrm{C}(50 \mathrm{ml}$ in $250 \mathrm{ml}$ flasks) in a New Brunswick Scientific orbital incubator at 280 r.p.m. for $24 \mathrm{~h}$.

Cell-free extracts. Cells were grown for $24 \mathrm{~h}$ in TSB medium (to the end of the exponential phase), collected by centrifugation at $10000 \mathrm{~g}$ for $15 \mathrm{~min}$ and washed twice with $0.9 \% \mathrm{NaCl}$ at $4{ }^{\circ} \mathrm{C}$. Washed cells (about $8 \mathrm{~g}$ wet wt per litre of culture) were either used immediately for enzyme purification or frozen at $-80^{\circ} \mathrm{C}$ for later use. Cells were disrupted by sonification (Kase \& Nakayama, 1974) as follows. Cells (5 $\mathrm{g}$ wet $w t)$ were suspended in $20 \mathrm{ml}$ of TM buffer (0.1 M-Tris/HCl, pH 8.0;0.02 M$\beta$-mercaptoethanol). Sonification was done for periods of $30 \mathrm{~s}$ with 1 min intervals in an ice-cooled tube using a Branson sonifier (model B12) at 75-100 W, until the cells were completely disrupted as observed microscopically. Cell debris was removed by centrifugation at $35000 \mathrm{~g}$ for $30 \mathrm{~min}$. The clear supernatant (S35) was dialysed overnight against 
TM buffer or filtered through Sephadex G-25 equilibrated with TM buffer. Enzyme extraction and purification were done at $0-4{ }^{\circ} \mathrm{C}$.

The dialysed S35 extract was used directly for enzyme assays or purified further (see below). The activity of S35 extracts frozen at $-80^{\circ} \mathrm{C}$ remained unchanged for at least 8 weeks. However, repeated thawing and freezing led to an irreversible loss of activity.

Purification of L-asparaginase. L-Asparaginase was partially purified in four sequential steps. Dialysed S35 extracts were mixed slowly with $0.1 \mathrm{vol} .1 \%(\mathrm{w} / \mathrm{v})$ protamine sulphate (Sigma) in TM buffer with gentle agitation for $20 \mathrm{~min}$. The nucleic acid precipitate was removed by centrifugation at $15000 \mathrm{~g}$ for $20 \mathrm{~min}$ and the supernatant was chromatographed through a DEAE-Sephacel (Pharmacia) anion exchange column equilibrated with TM buffer. The column was washed with $200 \mathrm{ml}$ of TM buffer and the proteins eluted with $200 \mathrm{ml}$ of a linear gradient $(0-0.5 \mathrm{M})$ of ammonium sulphate in TM buffer. The active fractions were collected, pooled and fractionated with increasing concentrations of ammonium sulphate (Sigma; enzyme grade). Most of the L-asparaginase activity precipitated in the $30-45 \%$ saturation fraction. The enzyme precipitate was dissolved in TM buffer and filtered through a Sephacryl S-200 or Sephadex G-200 column $(2.6 \times 100 \mathrm{~cm})$, eluting with TM buffer at a flow rate of $0.5 \mathrm{ml} \mathrm{min} \mathrm{m}^{-1}$. The $M_{\mathrm{r}}$ of L-asparaginase was calculated by comparison with globular proteins of known $M_{\mathrm{r}}$ (Pharmacia calibration kit). Partially purified preparations kept their activity when frozen at $-80^{\circ} \mathrm{C}$ but lost $50 \%$ of their activity in $5 \mathrm{~d}$ at $4^{\circ} \mathrm{C}$.

Protein concentration in the extracts was determined by the Lowry method, using BSA as standard.

Assay of L-asparaginase activity using hydroxylamine. The reaction mixture contained $25 \mu \mathrm{mol}$ L-asparagine, $400 \mu \mathrm{mol}$ hydroxylamine hydrochloride (neutralized to $\mathrm{pH} 7.0$ with $\mathrm{NaOH}$ ), $0.05-0.2$ units of enzyme and $100 \mu \mathrm{mol}$ Tris $/ \mathrm{HCl}, \mathrm{pH} 7.0$, in a final volume of $1.0 \mathrm{ml}$. The reaction mixture was incubated at $40{ }^{\circ} \mathrm{C}$ for $20 \mathrm{~min}$ except in temperature effect studies. The reaction was stopped by addition of $1.5 \mathrm{ml}$ of chromogenic iron chloride reagent $\left[\mathrm{FeCl}_{3}(100 \mathrm{~g})\right.$ and trichloroacetic acid $(33 \mathrm{~g})$ in 1 litre $0.7 \mathrm{M}-\mathrm{HCl}$ ] and centrifuged at $1800 \mathrm{~g}$. The aspartyl $\beta$-hydroxamate formed was quantified spectrophotometrically at $515 \mathrm{~nm}$ by comparison with a standard curve of pure aspartyl $\beta$-hydroxamate (Sigma). Control reactions without substrate (L-asparagine) or with heat-inactivated enzyme $\left(10 \mathrm{~min}\right.$ at $100^{\circ} \mathrm{C}$ ) were run in each experiment. An enzyme unit (U) was defined as the enzyme activity that forms $1 \mu \mathrm{mol}$ aspartyl $\beta$-hydroxamate $\min ^{-1}$ at $40^{\circ} \mathrm{C}$. Specific activities are given as $\mathrm{mU}(\mathrm{mg} \text { protein })^{-1}$.

HPLC assay of L-asparaginase activity. The reaction mixture, temperature and time were identical to those used in the hydroxylamine assay but hydroxylamine was not added to the reaction mixture. The reaction product, L-aspartic acid, was quantified by HPLC. The reaction was stopped by addition of 1 vol. of methanol and the reaction mixture was cooled in ice and centrifuged at $1800 \mathrm{~g}$. The amino acids in the supernatant were derivatized with $o$-phthaldialdehyde (OPA) according to the procedure of Jones et al. (1981). OPA-labelled amino acids were quantified after HPLC separation in a Varian 5000 chromatograph equipped with a Waters $420 \mathrm{AC}$ fluorescence detector, following the method of Vuillet et al. (1986) modified as follows: a reverse phase $\mathrm{C} 18 \mu$-Bondapak column (Waters) was used and the amino acids were eluted with $20 \%(\mathrm{v} / \mathrm{v})$ methanol in $0.02 \mathrm{M}$-potassium phosphate buffer, $\mathrm{pH} 7.0$, at a flow rate of $1.5 \mathrm{ml} \mathrm{min}^{-1}$.

$P A G E$. Non-denaturing PAGE of purified (98-fold) L-asparaginase was done essentially as described by Laemmli (1970) except that SDS was omitted. Electrophoresis was done at $4{ }^{\circ} \mathrm{C}$ in a vertical slab gel $\left\{170 \times 130 \times 1.5 \mathrm{~mm} ; 10 \%, \mathrm{w} / \mathrm{v}\right.$, polyacrylamide and $0.26 \% \mathrm{~N}, N^{\prime}$ methylene-bis-acrylamide as cross-linking agent (Hjerten, 1962)] at $100 \mathrm{~V}$ and $60 \mathrm{~mA}$.
After electrophoresis, part of the gel was stained with Coomassie brilliant blue R-250 and the other was used for in situ detection of $\mathrm{L}_{-}$ asparaginase. This part of the gel was submerged in reaction mixture containing hydroxylamine and incubated at $40^{\circ} \mathrm{C}$ for $30 \mathrm{~min}$. The reaction was stopped and the reaction product stained by addition of 1.5 vols of the iron chloride reagent. An ochre band was clearly visible in the gel.

The L-asparaginase was eluted in an active form from unstained preparative non-denaturing gels developed as above, and was used for further studies. Some samples of enzyme were used for $M_{\mathrm{r}}$ determination by SDS-PAGE, done as described by Laemmli (1970).

Chemicals. L- and D-amino acid substrates were obtained from Sigma or Merck. The protein calibration kit, Sephacryl S-200 and Sephadex G-200 were from Pharmacia. 5-Diazo-4-oxo-L-norvaline (DONV), an asparagine analogue, was kindly provided by R. E. Handschumacher, Yale University, USA. All other chemicals were of reagent quality.

\section{Results}

\section{L-Asparaginase activity in cell-free extracts}

Dialysed crude extracts showed high L-asparaginase activity using the hydroxylamine assay. Similar levels of L-asparaginase activity [about $20-21 \mathrm{mU}(\mathrm{mg} \text { protein })^{-1}$ ] were found after growth of $C$. glutamicum in TSB medium and in minimal medium. The enzyme was specific for L-asparagine and could not use $D$-asparagine or the $\mathrm{D}$ - or L- isomers of aspartic acid, glutamic acid and glutamine as substrates. However, non-dialysed extracts showed activity with L-aspartic acid as substrate due to the presence in the extracts of aspartokinase and aspartase activities.

The final product of the reaction mixtures without hydroxylamine was characterized by HPLC. Under these reaction conditions a clear peak of $\mathrm{L}$-aspartic acid (retention time $2.5 \mathrm{~min}$ ) was observed. The reaction proceeded with quantitative conversion of L-asparagine (retention time $9.0 \mathrm{~min}$ ) into L-aspartic acid. About 90 $95 \%$ of the L-asparagine was converted to L-aspartic acid after $30 \mathrm{~min}$ incubation. Similar apparent enzyme activities were obtained using HPLC analysis and the hydroxylamine method.

Optimal L-asparaginase activity was found at $\mathrm{pH} 7 \cdot 0$ and $40{ }^{\circ} \mathrm{C}$. The enzyme activity was slightly lower at $\mathrm{pH}$ values of 7.5 or 8.0 and decreased markedly at pH 6.5 . There was almost no activity at $\mathrm{pH} 6.0$. The reaction rate was linear for $30 \mathrm{~min}$ under optimal $\mathrm{pH}$ and temperature conditions, and also with increasing enzyme concentrations up to $0.2 \mathrm{U}$ of enzyme per $\mathrm{ml}$ of reaction mixture. The optimal parameters of the L-asparaginase did not change when the enzyme was purified.

\section{Purification of L-asparaginase}

L-Asparaginase was purified from $1554 \mathrm{mg}$ of soluble protein in $37 \mathrm{ml}$ of dialysed $\mathrm{S} 35$ extract. After removal of 
Table 1. Partial purification of L-asparaginase from C. glutamicum

\begin{tabular}{lcccccc}
\hline $\begin{array}{c}\text { Purification } \\
\text { step }\end{array}$ & $\begin{array}{c}\text { Vol. } \\
(\mathrm{ml})\end{array}$ & $\begin{array}{c}\text { Total } \\
\text { protein } \\
(\mathrm{mg})\end{array}$ & $\begin{array}{c}\text { Total } \\
\text { activity } \\
(\mathrm{U})\end{array}$ & $\begin{array}{c}\text { Specific } \\
\text { activity } \\
\text { [mU (mg protein) }\end{array}$ & $\begin{array}{c}\text { Recovery } \\
(\%)\end{array}$ & $\begin{array}{c}\text { Purification } \\
\text { (-fold) }\end{array}$ \\
\hline Cell extract & 37 & 1554 & 32 & 20.6 & 100 & 1 \\
Protamine sulphate & 39 & 1360 & $33 \cdot 6$ & 24.7 & 105 & $1 \cdot 2$ \\
DEAE-Sephacel & 14 & $82 \cdot 4$ & $11 \cdot 2$ & 136 & 35 & 6.6 \\
Ammonium sulphate & 2 & $15 \cdot 2$ & $5 \cdot 1$ & $335 \cdot 8$ & 16 & $16 \cdot 3$ \\
Sephacryl S-200 & $5 \cdot 5$ & 2 & 4 & 2020 & $12 \cdot 5$ & 98 \\
\hline
\end{tabular}

nucleic acids by protamine sulphate precipitation, the supernatant was passed through an anion exchange DEAE-Sephacel column. Elution with a linear gradient of ammonium sulphate gave a single symmetrical peak of L-asparaginase activity at $270 \mathrm{~mm}$-ammonium sulphate. The purification obtained in this step was 6.6-fold (Table 1). The active fractions were pooled, dialysed against TM buffer and fractionated with ammonium sulphate. L-Asparaginase was collected in the 30-45\% ammonium sulphate fraction at a specific activity of $335.6 \mathrm{mU}(\mathrm{mg}$ protein $^{-1}$ (16.3-fold purification). Best results were obtained when ammonium sulphate fractionation was done after ion-exchange chromatography rather than vice versa, since residual ammonium sulphate interfered with the ion-exchange chromatography when the fractionation was done before the ion-exchange step.

The $30-45 \%$ saturation ammonium sulphate precipitate was dissolved in $2 \mathrm{ml}$ of TM buffer, dialysed and fractionated by molecular sieving through a Sephacryl S-200 column. L-Asparaginase eluted as a clear symmetrical peak when the column was eluted with TM buffer. This step resulted in good purification (Table 1) with an accumulated purification factor of 98 . This purified preparation showed a major band of protein migrating in SDS-PAGE with a mobility corresponding to an $M_{\mathrm{r}}$ of about 81000 .

\section{$M_{\mathrm{r}}$ and kinetics}

The $M_{\mathrm{r}}$ was determined more precisely by gel filtration. The $K_{\text {av. }}$ value of 0.22 obtained was slightly smaller than the observed value for BSA and corresponded to an $M_{\mathrm{r}}$ of $80000 \pm 1000$, in good agreement with the value estimated by SDS-PAGE.

Normal saturation kinetics were obtained using Lasparagine as substrate in a Lineweaver-Burk double reciprocal plot. The apparent $K_{\mathrm{m}}$ of L-asparaginase for $\mathrm{L}$-asparagine was $2.5 \mathrm{mM}$. Neither D-asparagine nor L-glutamine nor any other related amino acid was a substrate for the enzyme. Neither of the two products of the reaction (aspartic acid and ammonium ion) exerted any inhibitory effect on enzyme activity up to a concentration of $100 \mathrm{mM}$.

Effect of DONV and other amino acids, and of cations on asparaginase activity

None of the 20 natural amino acids had any effect on Lasparaginase at concentrations upto $25 \mathrm{mM}$, even when the amino acid being tested was combined in a pair with aspartic acid, lysine, methionine, threonine, leucine, isoleucine, diaminopimelic acid or $s$-aminoethylcysteine. DONV, a structural analogue of L-asparagine (Handschumacher et al., 1968), inhibited L-asparaginase activity; the $K_{\mathrm{i}}$ was $2.7 \mathrm{mM}$.

$\mathrm{Mg}^{2+}, \mathrm{K}^{+}$and other monovalent and divalent cations did not affect enzyme activity at concentrations up to $150 \mathrm{~mm}$.

\section{Isolation of pure L-asparaginase by preparative gel electrophoresis}

The purified (98-fold) enzyme preparation showed two bands after staining with Coomasssie brilliant blue (Fig. 1). Only the faster-moving of the two bands gave a positive L-asparaginase reaction, forming an ochre colour when incubated with hydroxylamine and stained with the iron chloride reagent (Fig. 1).

Both protein bands were electroeluted separately from the gel. In vitro, only the protein eluted from the fastermoving band gave a positive L-asparaginase reaction.

A sample of the eluted protein that had L-asparaginase activity was denatured with SDS. On SDS-PAGE this protein moved as a single band with an $M_{\mathrm{r}}$ of 81000 .

\section{Discussion}

L-Asparaginase is present in different forms in the microorganisms in which it has been studied. In the Achromobacteriaceae, a single protein has been reported 


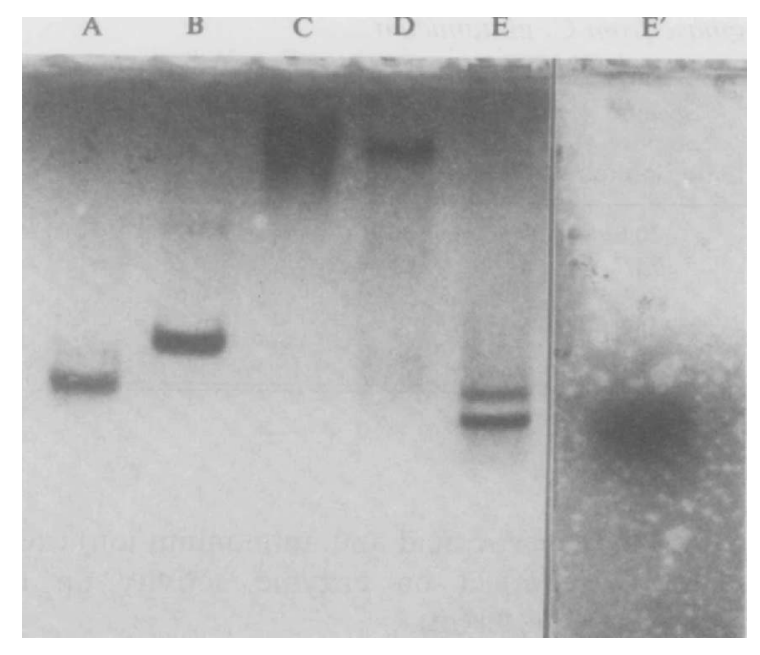

Fig. 1. Non-denaturing PAGE of the asparaginase of $C$. glutamicum after four purification steps. Left, Coomassie blue stained-gel: lane A, ovalbumin; B, BSA ; C, aldolase; D, catalase; E, asparaginase (note the presence of two bands). Right, lane $E^{\prime}$ stained in situ for-asparaginase activity (only the faster band is stained).

to have both asparaginase and glutaminase activity (Roberts et al., 1972). In E. coli two independent proteins with asparaginase activity have been reported: one is located in the cytoplasm whereas the second is periplasmic (Willis \& Woolfolk, 1974; Del Casale et al., 1983). In Vibrio succinogenes there is a single protein with asparaginase activity only (Kafkewitz \& Goodman, 1974). In C. glutamicum we have found that there is only a single asparaginase which has no glutaminase activity. Special care must be taken in interpreting results concerning the existence of more than one asparaginase in cell-free extracts when the enzyme activity is assayed by the hydroxylamine method, since acyl phosphate intermediates formed by various enzymes are easily converted into the corresponding hydroxamates, all of which react with iron chloride reagent. Characterization of the reaction product(s) by HPLC or other techniques is obligatory. Two other enzyme activities in extracts of C. glutamicum giving a positive reaction with hydroxylamine were identified as aspartase and aspartokinase (unpublished results).

The L-asparaginases of different micro-organisms have different substrate affinities and probably play different physiological roles. The enzyme from $C$. glutamicum showed an apparent $K_{\mathrm{m}}$ of $2.5 \mathrm{mM}$ for Lasparagine, a value very similar to the $K_{\mathrm{m}}$ of the cytoplasmic asparaginase I of E. coli $\left(K_{\mathrm{m}} 3.5 \mathrm{mM}\right)$ (Willis $\&$ Woolfolk, 1974). These two enzymes have a low substrate affinity compared to the periplasmic asparaginase (so-called asparaginase II) of E. coli $\left(K_{\mathrm{m}} 0.01 \mathrm{mM}\right)$ or with the constitutive asparaginase of $V$. succinogenes
$\left(K_{\mathrm{m}} \mathbf{0 . 0 1 7} \mathrm{mM}\right)$. This suggests that the $C$. glutamicum asparaginase may have a role similar to the cytoplasmic asparaginase of $E$. coli. The latter seems to be an overflow enzyme converting excess asparagine in the cytoplasm to aspartic acid in contrast to the periplasmic enzyme which probably acts as a scavenger of asparagine in the extracellular fluid. Mutants of $E$. coli defective in cytoplasmic asparaginase have been isolated. This mutation is located in the asn $A$ locus and has been mapped at minute 39 of the $E$. coli chromosome map (Del Casale et al., 1983; Bachmann, 1983).

We found similar levels of enzyme activity - about $20 \mathrm{mU}$ (mg protein $)^{-1}$ - in either complex or minimal media; the value did not change significantly with the age of the culture suggesting that the $L$-asparaginase of $C$. glutamicum might be constitutive, as in $V$. succinogenes. The pure enzyme had no apparent cofactor requirement, was relatively stable and was not affected by ions or amino acids. These results are of interest in the context of amino acid biosynthesis in C. glutamicum, which overproduces lysine and threonine (Ishino et al., 1984). Both of these amino acids are derived from aspartic acid, which we have identified as the limiting precursor in vivo of the pathway (unpublished results). L-Asparagine is present in many of the peptones and proteins used in culture media for production of amino acids. Furthermore, L-asparagine may be formed in excess, especially in media supplemented with ammonium salts or urea which are used industrially both as nitrogen sources and as buffering agents. Under these conditions the Lasparaginase of $C$. glutamicum probably acts as an overflow enzyme converting asparagine into aspartic acid.

The similarity of the $C$. glutamicum enzyme to asparaginase $\mathrm{I}$ of $E$. coli is further supported by the sensitivity of both enzymes to inhibition by DONV, a substrate analogue. Finally, the L-asparaginase of $C$. glutamicum could have antitumour activity similar to those of other asparaginases. The availability of a new asparaginase for comparative structure-activity relationships in antitumour studies may be of great interest.

This research work was supported by a grant of the CICYT, Madrid, Spain (BT85 0024). We acknowledge the gift of DONV from R. E. Handschumacher, Yale University, USA, and thank J. Cortes and R. M. Sarmiento for valuable suggestions and M. I. Corrales, B. Martín and M. P. Puertas for excellent technical assistance.

\section{References}

Abe, S., Takayama, K. I. \& Kinoshita, K. S. (1967). Taxonomical studies on glutamic acid-producing bacteria. Journal of General and Applied Microbiology 13, 279-301.

BACHMANN, B. J. (1983). Linkage map of Escherichia coli K-12. Edition 7. Microbiological Reviews 47, 180-230. 
Del Casale, T., Sollitti, P. \& Chesney, R. H. (1983). Cytoplasmic Lasparaginase: isolation of a defective strain and mapping of $a s n A$. Journal of Bacteriology 154, 513-515.

Handschumacher, R. E., Bates, C. J., Chang, P. K., Andrews, A. T. \& FisCHER, G. A. (1968). 5-Diazo-4-oxo-L-norvaline: reactive asparagine analog with biological specificity. Science 161, 62-63.

HJERTEN, S. (1962). Molecular sieve chromatography on polyacrylamide gels, prepared according to a simplified method. Archives of Biochemistry and Biophysics suppl. 1, 147-151.

Ishino, S., Yamaguchi, K., Shirahata, K. \& ARaki, K. (1984). Involvement of meso- $\alpha, \varepsilon$-diaminopimelate $D$-dehydrogenase in lysine biosynthesis in Corynebacterium glutamicum. Agricultural and Biological Chemistry 48, 2557-2560.

Jones, B. N., PaAbo, S. \& Stein, S. (1981). Amino acid analysis and enzymatic sequence determination of peptides by an improved $o^{-}$ phthaldialdehyde precolumn labeling procedure. Journal of Liquid Chromatography 4, 565-586.

KAFKEWITZ, D. \& GOODMAN, D. (1974). L-Asparaginase production by the rumen anaerobe Vibrio succinogenes. Applied Microbiology 27, 206-209.

KASE, H. \& Nakayama, K. (1974). Mechanism of L-threonine and Llysine production by analog-resistant mutants of Corynebacterium glutamicum. Agricultural and Biological Chemistry 38, 993-1000.
Kinoshita, S., Nakayama, K. \& Akita, S. (1958). Production of Lglutamic acid. Bulletin of the Agricultural Chemical Society of Japan 22, 176-185.

LAEMMLI, U. K. (1970). Cleavage of structural proteins during the assembly of the head of bacteriophage T4. Nature, London 227, 680685.

MARTín, J. F. (1989). Molecular genetics of amino acid-producing corynebacteria. Symposia of the Society for General Microbiology 44, 25-59.

Martín, J. F., Santamaria, R., Sandoval, M., Mateos, L. M., Gil J. A. \& Aguilar, A. (1987). Cloning systems in amino acidproducing corynebacteria. Bio/Technology 5, 137-146.

ROBERTS, J., HOLCENBERG, J. S. \& DoloWY, W. C. (1972). Isolation, crystallization, and properties of Achromobacteriaceae glutaminase-asparaginase with antitumour activity. Journal of Biological Chemistry 247, 84-90.

Vuillet, S., Spinnler, H. E. \& Blachere, H. (1986). Analysis of amino acid requirements of Clostridium thermocellum. Applied Microbiology and Biotechnology 23, 496-498.

WILlIS, R. C. \& WoolfolK, R. (1974). Asparagine utilization in Escherichia coli. Journal of Bacteriology 118, 231-241.

Wriston, J. C. (1970). Asparaginase. Methods in Enzymology 17A, $732-742$. 